\title{
THE RELATION OF POSTURAL HEMODILUTION TO PAROXYSMAL DYSPNEA
}

\author{
By GEORGE A. PERERA AND ROBERT W. BERLINER 1 \\ (From the Department of Medicine, College of Physicians and Surgeons, Columbia University, \\ and the Presbyterian Hospital, New York City)
}

(Received for publication May 25, 1942)

\section{INTRODUCTION}

For many years, there has been considerable speculation about the mechanism of paroxysmal dyspnea. Changes in vasomotor, neural, cardiac, and respiratory physiology, nightmares and other trigger mechanisms, and alterations in blood volume have been variously suggested as responsible for the characteristic nocturnal attacks. The present study was undertaken to see whether shifts of body fluid to the blood stream, following rest in the horizontal position, could be correlated with the time of onset of paroxysmal dyspnea and might therefore be considered a factor in inducing acute left-sided heart failure.

Böhme (1) early noted a fall in serum proteins after rest, a rise after periods of exercise; and other workers ( 2 to 5 ) have published results indicating that the change from recumbency to an upright position may be followed by a rise in protein concentration, usually ranging from 10 to 20 per cent. Similar changes in the composition and volume of the blood have also been reported (3, $5,6)$. Since the introduction of the concept of "cardiac asthma" (7), reviewers of the subject $(8,9)$ have pointed out the frequently nocturnal character of these episodes, which usually occur at rest and in the horizontal position. Weiss and Robb (9) have suggested that patients with low plasma proteins are more susceptible to severe attacks.

\section{EXPERIMENTAL AND RESULTS}

Serum protein determinations were first made at 2-hourly intervals, throughout the day and night, on a group of 10 normal ambulatory young adults, 10 constantly-recumbent bed patients without heart disease, and 10 ambulatory patients who had chronic cardiac insufficiency, including dependent edema. The serum proteins were determined by a specific gravity gradient tube, Lowry's

1 Dazian Fellow. modification of the micro-method of Linderstr $\not \mathrm{m}$ Lang $(10,11)$, checked frequently with the microKjeldahl method, and found to measure specific gravity with no greater than a 0.0002 variation. The results are shown in Table I, with the average figures graphically recorded (Figure 1).

It was obvious that a significant and consistent fall in serum proteins, averaging about 0.8 gram per $100 \mathrm{cc}$., occurred at night in ambulatory individuals, that the values did not rise during the day in those patients confined to bed. Patients with edema demonstrated no greater hemodilution in the recumbent position than did the normals, but it should be remembered that they were of necessity less active. A further confirmation of these changes was obtained by comparing the diurnal serum protein fluctuations of a bed patient with those found a week later when the same patient became ambulatory (Figure 2). Repeated observations on persons staying up all night and sleeping during the day, made it evident that bed rest was associated with an invariable and significant drop in serum proteins from the levels achieved when up and about. Fractionation of the serum proteins showed that the changes observed involved both albumin and globulin equally, although in a larger series significant differences might appear.

In order to evaluate the relative roles of physical activity and position, 5 normal adults rested for 45 minutes in the horizontal position, then walked rapidly for 5 minutes. Blood specimens were taken at the start and close of the exercise period. The same procedure was carried out after a preliminary rest period using a tilt-table, with the patients then raised to $60^{\circ}$ for 5 minutes and lying quietly throughout the experiment. Walking caused a rise in serum protein of 0.3 to 0.6 (average 0.48 ) gram per $100 \mathrm{cc}$,, while a 5-minute change in position without activity produced a rise of from 0.2 to 0.3 (average 0.26 ) gram per 100 cc. 
TABLE I

Diurnal serum protein fluctuations

\begin{tabular}{|c|c|c|c|c|c|c|c|c|c|c|c|c|c|}
\hline & Case & 10 a.m. & $12 \mathrm{n}$. & 2 p.m. & 4 p.m. & 6 p.m. & 8 p.m. & 10 p.m. & $12 \mathrm{~m}$. & 2 a.m. & 4 a.m. & 6 a.m. & 8 a.m. \\
\hline 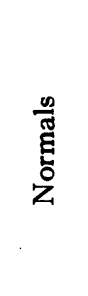 & $\begin{array}{r}1 \\
2 \\
3 \\
4 \\
5 \\
6 \\
7 \\
8 \\
9 \\
10\end{array}$ & $\begin{array}{l}6.5 \\
6.3 \\
6.8 \\
6.7 \\
7.1 \\
7.1 \\
7.3 \\
6.7 \\
6.7\end{array}$ & $\begin{array}{l}6.4 \\
6.2 \\
6.8 \\
6.6 \\
7.1 \\
6.7 \\
7.0 \\
7.2 \\
6.7 \\
6.8\end{array}$ & $\begin{array}{l}6.3 \\
6.3 \\
6.5 \\
\\
6.8 \\
6.7 \\
\\
7.0 \\
6.8 \\
6.6\end{array}$ & $\begin{array}{l}6.6 \\
6.3 \\
6.6 \\
6.8 \\
7.2 \\
7.2 \\
7.0 \\
6.6 \\
7.1\end{array}$ & $\begin{array}{l}6.4 \\
6.2 \\
6.8 \\
6.8 \\
6.9 \\
7.2 \\
7.3 \\
7.2 \\
6.8 \\
7.1\end{array}$ & $\begin{array}{l}7.0 \\
6.2 \\
6.4 \\
6.7 \\
7.0 \\
6.6 \\
7.3 \\
6.8 \\
6.5 \\
7.2\end{array}$ & $\begin{array}{l}6.5 \\
6.3 \\
6.1 \\
6.6 \\
7.0 \\
6.5 \\
7.1 \\
6.8 \\
6.5 \\
6.8\end{array}$ & $\begin{array}{l}6.1 \\
6.0 \\
6.1 \\
6.3 \\
6.8 \\
6.2 \\
6.9 \\
7.0 \\
6.5 \\
6.9\end{array}$ & $\begin{array}{l}5.8 \\
5.7 \\
5.9 \\
6.2 \\
6.4 \\
6.0 \\
6.2 \\
6.3 \\
5.9 \\
5.9\end{array}$ & $\begin{array}{l}5.7 \\
5.5 \\
6.0 \\
6.0 \\
6.2 \\
6.0 \\
6.2 \\
6.3 \\
6.1 \\
5.9\end{array}$ & $\begin{array}{l}5.9 \\
5.4 \\
6.0 \\
5.9 \\
6.2 \\
6.2 \\
6.3 \\
6.1 \\
5.9 \\
5.8\end{array}$ & $\begin{array}{l}6.7 \\
5.9 \\
6.8 \\
7.2 \\
6.9 \\
7.0 \\
7.1 \\
7.2 \\
6.5 \\
6.5\end{array}$ \\
\hline 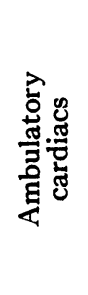 & $\begin{array}{r}1 \\
2 \\
3 \\
4 \\
5 \\
6 \\
7 \\
8 \\
9 \\
10\end{array}$ & $\begin{array}{l}7.1 \\
6.8 \\
6.5 \\
6.8 \\
7.4 \\
6.2 \\
5.9 \\
6.9 \\
6.9 \\
7.0\end{array}$ & $\begin{array}{l}7.2 \\
7.0 \\
6.5 \\
6.5 \\
7.5 \\
6.4 \\
5.7 \\
7.0 \\
6.5 \\
7.0\end{array}$ & $\begin{array}{l}7.2 \\
7.2 \\
6.4 \\
6.6 \\
7.3 \\
6.5 \\
6.0 \\
6.9 \\
6.7 \\
6.8\end{array}$ & $\begin{array}{l}7.3 \\
6.9 \\
6.4 \\
6.7 \\
7.2 \\
6.1 \\
5.8 \\
7.0 \\
6.7 \\
6.9\end{array}$ & $\begin{array}{l}7.1 \\
6.8 \\
6.6 \\
6.8 \\
7.4 \\
6.3 \\
5.8 \\
6.8 \\
6.8 \\
7.1\end{array}$ & $\begin{array}{l}7.1 \\
7.0 \\
6.5 \\
6.6 \\
7.5 \\
6.3 \\
5.8 \\
6.8 \\
6.6 \\
6.7\end{array}$ & $\begin{array}{l}6.6 \\
6.8 \\
6.2 \\
6.5 \\
7.0 \\
6.0 \\
5.4 \\
6.3 \\
6.3 \\
6.6\end{array}$ & $\begin{array}{l}6.4 \\
6.2 \\
5.4 \\
6.0 \\
6.7 \\
5.8 \\
5.0 \\
6.0 \\
6.4 \\
6.3\end{array}$ & $\begin{array}{l}6.3 \\
6.0 \\
5.5 \\
5.9 \\
6.6 \\
5.7 \\
4.9 \\
5.8 \\
6.2 \\
6.0\end{array}$ & $\begin{array}{l}6.4 \\
5.9 \\
5.4 \\
6.0 \\
6.8 \\
5.7 \\
5.0 \\
6.0 \\
6.2 \\
6.0\end{array}$ & $\begin{array}{l}6.9 \\
6.1 \\
5.7 \\
5.9 \\
7.0 \\
5.9 \\
5.1 \\
6.0 \\
6.4 \\
6.2\end{array}$ & $\begin{array}{l}7.1 \\
7.0 \\
6.3 \\
6.7 \\
7.5 \\
6.3 \\
5.8 \\
6.8 \\
6.7 \\
6.9\end{array}$ \\
\hline 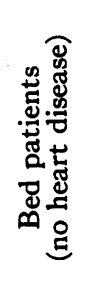 & $\begin{array}{r}1 \\
2 \\
3 \\
4 \\
5 \\
6 \\
7 \\
8 \\
9 \\
10\end{array}$ & $\begin{array}{l}6.2 \\
6.4 \\
6.3 \\
6.1 \\
\\
5.3 \\
5.4 \\
6.1 \\
6.5\end{array}$ & $\begin{array}{l}6.3 \\
6.2 \\
6.3 \\
5.4 \\
4.8 \\
5.6 \\
5.2 \\
5.9 \\
6.2\end{array}$ & $\begin{array}{l}6.4 \\
6.3 \\
6.2 \\
6.3 \\
5.2 \\
5.3 \\
5.6 \\
5.3 \\
6.2 \\
6.5\end{array}$ & $\begin{array}{l}6.6 \\
6.3 \\
5.6 \\
5.3 \\
4.8 \\
5.4 \\
5.3 \\
6.3 \\
6.4\end{array}$ & $\begin{array}{l}6.5 \\
6.3 \\
6.3 \\
6.0 \\
5.3 \\
4.8 \\
5.4 \\
5.3 \\
6.1 \\
6.4\end{array}$ & $\begin{array}{l}6.5 \\
6.4 \\
6.3 \\
6.0 \\
5.3 \\
5.0 \\
5.2 \\
5.4 \\
6.1 \\
6.3\end{array}$ & $\begin{array}{l}6.1 \\
6.4 \\
6.0 \\
6.0 \\
5.4 \\
5.0 \\
5.2 \\
5.4 \\
6.2 \\
6.5\end{array}$ & $\begin{array}{l}6.0 \\
6.3 \\
6.1 \\
5.9 \\
5.4 \\
5.0 \\
5.4 \\
5.3 \\
5.9 \\
6.1\end{array}$ & $\begin{array}{l}5.7 \\
6.3 \\
6.2 \\
\\
5.4 \\
4.6 \\
5.5 \\
5.9 \\
6.1\end{array}$ & $\begin{array}{l}5.8 \\
6.2 \\
6.2 \\
6.0 \\
4.7 \\
5.4 \\
5.3 \\
6.1 \\
6.2\end{array}$ & $\begin{array}{l}5.9 \\
6.3 \\
5.8 \\
5.5 \\
4.9 \\
5.3 \\
5.2 \\
6.3 \\
6.1\end{array}$ & $\begin{array}{l}6.6 \\
6.4 \\
6.5 \\
6.0\end{array}$ \\
\hline
\end{tabular}

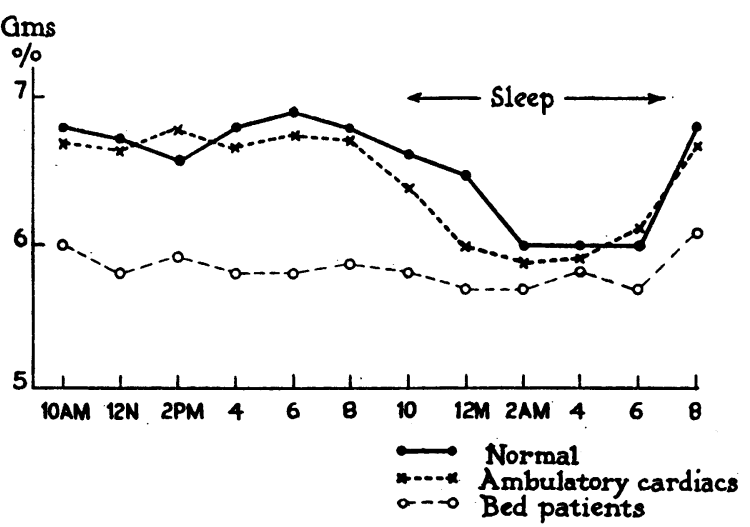

Fig. 1. Average Diurnal Serum Protein Fluctuations

Simultaneous serum protein, red cell count, hematocrit, mean red cell diameter, vital capacity, and venous pressure determinations were carried out on 10 normal individuals at 4 p.m. and 11 p.m., using venous blood in all instances, the night data being secured after at least one hour of bed rest or sleep. Venous pressures were taken in the horizontal position, vital capacities while sitting, after the other procedures had been completed. A fall in erythrocyte count of between 180,000 and 370,000 , a drop in hematocrit of from 2 to 3 per cent cells in every case, as well as the expected serum protein fall, offered further evidence of hemodilution after horizontal rest. No change in mean corpuscular volume or red cell diameter was observed. In 8 of these 10 normal subjects, there was a 100 to $400 \mathrm{cc}$. reduction in vital capacity and a 5 to $20 \mathrm{~mm}$. rise in venous pressure after the

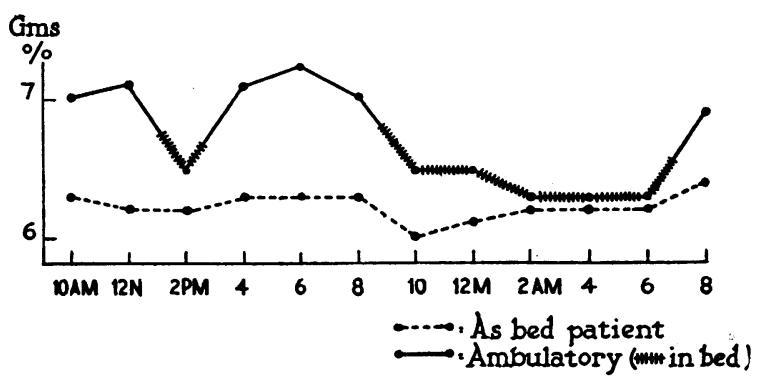

Fig. 2. Effect of Altered Activity on Serum Protein Values 
recumbent position had been assumed for an hour or more.

Finally, serum protein, vital capacity, and venous pressure measurements were made on 8 patients with paroxysmal dyspnea as the presenting symptom of established arteriosclerotic coronary or hypertensive cardiovascular disease. These patients were allowed to be ambulatory during the day, data being secured at 4 p.m., several hours after going to bed (11 p.m. to midnight), and again 10 to 15 minutes after the onset of a characteristic attack (while still sitting up in bed and short of breath).

TABLE II

Observations on patients with paroxysmal dyspnea

\begin{tabular}{|c|c|c|c|c|c|c|c|c|c|c|}
\hline \multirow{2}{*}{ שّ } & \multicolumn{3}{|c|}{4 p.m. } & \multicolumn{3}{|c|}{$\begin{array}{l}11 \text { p.m. to } \\
\text { midnight }\end{array}$} & \multicolumn{3}{|c|}{$\begin{array}{l}10 \text { to } 15 \text { minutes } \\
\text { after onset of } \\
\text { paroxysmal } \\
\text { dyspnea }\end{array}$} & \multirow{2}{*}{$\begin{array}{l}\text { Time of } \\
\text { attack }\end{array}$} \\
\hline & 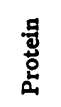 & 号嗬 & 造 & 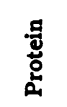 & 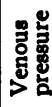 & 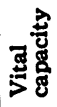 & $\begin{array}{l}\text { 물 } \\
\text { 임 }\end{array}$ & 总总 & 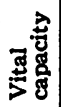 & \\
\hline & $\begin{array}{l}\text { grams } \\
\text { per } \\
\text { cent }\end{array}$ & ${ }_{H} m_{2} \mathrm{O}$ & $c c$. & $\begin{array}{l}\text { grams } \\
\text { per } \\
\text { cent }\end{array}$ & $\operatorname{mm}_{H=0}$ & cc. & $\begin{array}{l}\text { grams } \\
\text { per } \\
\text { cent }\end{array}$ & ${ }_{H} m_{20}$ & cc. & \\
\hline 1 & 7.7 & 95 & 2550 & 6.8 & 90 & 2100 & 7.5 & 120 & 1650 & 2:30 a.m. \\
\hline 2 & 6.3 & 80 & 2800 & 5.6 & 100 & 2500 & 6.4 & 150 & 2300 & 4:00 a.m. \\
\hline 3 & 6.5 & 65 & 3100 & 5.5 & 80 & 3100 & 6.4 & 110 & 2700 & 12:50 a.m. \\
\hline 4 & 6.0 & 110 & 2900 & 5.5 & 115 & 2650 & 6.1 & 120 & 2500 & 3 a.m. \\
\hline 5 & 6.3 & 100 & 2000 & 5.6 & 120 & 1900 & 6.2 & 145 & 1600 & 3 a.m. \\
\hline 6 & 5.9 & 70 & 2200 & 5.1 & 100 & 2000 & 5.6 & 110 & 1750 & 4:45 a.m. \\
\hline 7 & 6.6 & 100 & 3400 & 5.8 & 110 & 3050 & 6.3 & 130 & 2800 & 5:00 a.m. \\
\hline 8 & 6.3 & 120 & 1900 & 5.6 & 115 & 1600 & 6.0 & 140 & 1500 & 3:15 a.m. \\
\hline
\end{tabular}

From these figures (Table II), it could be appreciated that the usual serum protein drop after bed rest was followed by a significant and rapid rise during the episode of paroxysmal dyspnea, that period in which the patient awakens, and sits or stands up, gasping for air. In other words, not only did the attacks occur at a time when serum proteins were normally found to be reduced, but the maneuvers of the breathless patient, which characteristically alleviate an attack, were those experimentally shown to cause an elevation in serum proteins. Again, in the majority of instances, the vital capacity was found to be reduced after going to bed, while venous pressures tended to increase. These changes became more pronounced during the attacks of dyspnea. Arte- rial pressures were followed in 3 of these patients. The day and night values were essentially unchanged, 2 of the 3 exhibiting a $15 \mathrm{~mm}$. systolic rise during the paroxysm.

\section{DISCUSSION}

Many investigators have long been aware of the change in serum protein concentration due to alterations in position and muscular activity, a fact which has not however been emphasized in the clinic. A diurnal fluctuation of 10 to 15 per cent, dependent upon postural factors, has been shown in this study to occur regularly in individuals carrying on a normal existence. This fact offers an explanation for the common observation that the average serum protein values of hospitalized patients are lower than those found in healthy ambulatory subjects. Thus the normal serum proteins, as measured in the recumbent position, are often as low as $\mathbf{5 . 5}$ to 6.0 grams per $100 \mathrm{cc}$., levels frequently regarded as pathological. These changes are often attributed to illness, under-nutrition, shock, or operative protein loss, whereas the position and inactivity of the bed patient may provide an adequate explanation. It should be noted that a significant change can occur in a few minutes, although a longer period is required for a maximal effect.

In view of the comparable alterations in red blood count and hematocrit measurements, which also indicate hemoconcentration in the standing position or during activity, there can be little doubt that the rise in serum proteins results primarily from the loss of fluid from the circulation. Furthermore, plasma volume studies by Thompson and his co-workers ( 3 ), showing an 11 per cent drop after standing, and the observations of Gregersen (12), indicating even greater changes after exercise, using the blue dye T.1824, support this idea.

The suggestion of a slightly greater degree of venous and pulmonary congestion in the quiet recumbent state, as judged by venous pressure and vital capacity, is in accord with the concept of a larger and more dilute blood volume at that time, and the possibility that fluids from dependent portions of the body have become redistributed to other sites with a change in position. However, with vasomotor and peripheral factors entering 
into the accuracy of venous pressure measurements and with variations in cooperation on the part of the patient in the case of vital capacity determinations, speculation on the lack of parallelism between the serum protein changes and the venous pressure and vital capacity readings appears inadvisable and interpretation of the results must be guarded.

It is generally recognized that paroxysmal dyspnea usually occurs at night or during rest, particularly during the early morning hours, in other words at those times when, in accordance with our observations, serum proteins reach their lowest levels. The effect of the horizontal position upon the resting individual is comparable to the administration of a slow but sustained infusion. It seems probable, therefore, that in a patient already subjected to left ventricular strain by virtue of underlying organic disease, the increase in circulating plasma volume accompanying rest in the horizontal position may prove a significant factor in inducing paroxysmal dyspnea and pulmonary edema. In support of this idea is the evidence presented first by Caughey (13) that infusions or transfusions consistently cause a reduction in vital capacity, and may provoke pulmonary edema in cardiac patients. Murphy and his associates have also shown that an infusion of as little as $100 \mathrm{cc}$. of a 50 per cent dextrose solution intravenously may have a similar deleterious effect on such patients (14). Furthermore, Burwell (15) has recently shown that a 50 per cent increase in blood volume can cause many of the phenomena of congestive failure in normal dogs.

\section{SUMMARY}

1. It has been confirmed that serum protein concentrations are considerably altered in health and disease by changes in position and by muscular activity.

2. This decrease in serum protein concentration appears to be the result of hemodilution, due to an increase in plasma volume.

3. The close correlation between nocturnal hemodilution and attacks of paroxysmal dyspnea suggests that an increase in plasma volume is an important factor in the production of acute leftsided failure in individuals with organic heart disease.
4. Clinical interpretations of protein values must be made with caution since an average fall of 0.8 gram per $100 \mathrm{cc}$. is encountered after rest in the horizontal position.

We are indebted to Doctor Robert F. Loeb for his valuable help in the preparation of this paper.

\section{BIBLIOGRAPHY}

1. Böhme, A., Ueber die Schwankungen der Serumkonzentration beim gesunden Menschen. Deutsches Arch. f. klin. Med., 1911, 103, 522.

2. Cipriani, C., and Moracchini, R., Comportamento del siero di sangue e della diuresi nell'ortostatismo. Minerva med., 1925, 5, 261.

3. Thompson, W. O., Thompson, P. K., and Dailey, M. E., The effect of posture upon the composition and volume of the blood in man. J. Clin. Invest., 1928, $5,573$.

4. Lang, $K$., Ueber die Tagesschwankung in dem Schwefel- und Tryptophangehalt der menschlichen Serumeiweisskörper. Arch. f. exper. Path. u. Pharmakol., 1930, 154, 342.

5. Youmans, J. B., Wells, H. S., Donley, D., and Miller, D. G., The effect of posture (standing) on the serum protein concentration and colloid osmotic pressure of blood from the foot in relation to the formation of edema. J. Clin. Invest., 1934, 13, 447.

6. Waterfield, R. L., The effects of posture on the circulating blood volume. J. Physiol., 1931, 72, 110.

7. Hope, J., A Treatise on the Diseases of the Heart. London, 1839, ed. 3, p. 393.

8. Pratt, J. H., Cardiac asthma. J. A. M. A., 1926, 87, 809.

9. Weiss, S., and Robb, G. P., Cardiac asthma (paroxysmal cardiac dyspnea) and the syndrome of left ventricular faílure. J. A. M. A., 1933, 100, 1841.

10. Linderstr $\phi \mathrm{m}$-Lang, K., and Lanz, H., Jr., Dilatometric micro-estimation of peptidase activity. Compt. rend. de trav. du lab. Carlsberg, 1938, 21, 315.

11. Lowry, O. H., and Hastings, A. B., Histochemical changes associated with aging. I. Methods and calculations. J. Biol. Chem., 1942, 143, 257.

12. Gregersen, M. I., Personal communication.

13. Caughey, J. L., Jr., Effect of rapid infusion on venous pressure: a test of cardiac reserve. Proc. Soc. Exper. Biol. and Med., 1935, 32, 973.

14. Murphy, F. D., Correll, H., and Grill, J. C., The effects of intravenous solutions on patients with or without cardiovascular defects. J. A. M. A., 1941, 116, 104.

15. Burwell, C. S., The pathological physiology of the early manifestations of left ventricular failure. Ann. Int. Med., 1942, 16, 104. 